\title{
COMBINATION OF TWO ODOUR CHEMICAL LURES DOES NOT INCREASE THRIPS CAPTURE IN FIELD BIOASSAYS
}

\author{
D.A.J. TEULON ${ }^{1}$, M-C. NIELSEN ${ }^{1}$, D.E. JAMES ${ }^{1}$, S. WINKLER ${ }^{2}$, \\ A.R.G. MCLACHLAN ${ }^{3}$ and N.B. PERRY ${ }^{4}$ \\ ${ }^{1}$ Crop \& Food Research, Private Bag 4704, Christchurch, New Zealand \\ ${ }^{2}$ Crop \& Food Research, Private Bag 92169, Auckland, New Zealand \\ ${ }^{3}$ Crop \& Food Research, Private Bag 11600, Palmerston North, New Zealand \\ ${ }^{4}$ Crop \& Food Research, Box 56, Dunedin, New Zealand \\ Corresponding author: teulond@crop.cri.nz
}

\begin{abstract}
Used in isolation, several odour chemicals are known to increase trap capture of some thrips, especially flower-inhabiting species. This study examined the combined use of two structurally distinct odour chemicals, both known to increase thrips trap capture in isolation. Field bioassays using water traps were undertaken at two sites in New Zealand to target different thrips species. Water traps had (1) no odour (water), (2) $p$-anisaldehyde only, (3) methyl isonicotinate only, (4) $p$ anisaldehyde and methyl isonicotinate mixed together in the same vial or (5) $p$-anisaldehyde and methyl isonicotinate placed separately in adjacent vials. Thrips tabaci was the most common thrips species trapped at both sites $(>92 \%)$. Most odour treatments increased trap capture of T. tabaci compared with the controls ( $p$-anisaldehyde by 1.8 and $7 \times$, methyl isonicotinate by 5 and $30 \times$ ) but treatments with the two chemicals combined did not increase trap capture above the level of methyl isonicotinate alone, at both sites.

Keywords: Thrips tabaci, odour, trapping, lures, chemical mixtures, p-anisaldehyde, methyl isonicotinate.
\end{abstract}

\section{INTRODUCTION}

Thrips (Thysanoptera) are important pests of a range of plants in agriculture, horticulture and forestry (Lewis 1997) and effective thrips traps are an important tool for pest management and biosecurity. More effective thrips traps would be a useful tool for monitoring thrips at low population densities (i.e. early infestations or in eradication attempts) and to reduce thrips numbers for control. Some odour chemicals are known to increase trap capture of certain thrips by up to 100 times (e.g. flower-inhabiting species), but the effect is usually much lower (Kirk 1985; Teulon et al. 1993; Murai et al. 2000; Imai et al. 2001). For some insects, combinations of odours are known to improve trap capture compared with odours used in isolation (Robacker et al. 1992; Rappaport et al. 2000; Landolt et al. 2001; Aldrich et al. 2004), although decreased capture has also been reported (Robacker \& Heath 1997; Zhang \& Schlyter 2004). There has been no published report on the response of thrips to odour mixtures except for their cursory use by Teulon et al. (2005). The combined use of odour chemicals might be one way of improving the effectiveness of thrips traps, either by an additive or multiplicative (synergistic) effect.

This paper describes two field experiments to examine the effect of chemical mixtures on thrips capture in water traps. Combinations of two odour chemicals that are known thrips lures and are structurally different were tested. $p$-anisaldehyde is a well known 
thrips lure and is found in host plants (flowers) of many thrips species (Terry 1997). Methyl isonicotinate is a newly discovered thrips lure that has not yet been recorded from thrips host plants (Davidson et al. 2005). The two compounds are chemically distinct; $p$-anisaldehyde is a methoxy substituted benzene aldehyde and methyl isonicotinate is a methyl ester of carboxy substituted pyridine. This research targeted two thrips species known to respond to these chemical odours (D.A.J. Teulon, unpubl. data; M.M. Davidson unpubl. data). Onion thrips (Thrips tabaci Lindeman) and western flower thrips (Frankliniella occidentalis Pergande), both polyphagous, are major pests of several crops throughout the world (Lewis 1997) and are vectors of plant-damaging tospoviruses (Mound 1996). In New Zealand, flights of onion thrips have been recorded from spring to autumn (Teulon \& Penman 1996; Nielsen et al. 2004). In contrast, the western flower thrips is mainly found indoors (Teulon \& Nielsen 2005), but populations have been found on outdoor lettuces since 2003 at the Pukekohe Research Station (P.J. Workman, pers. comm.).

\section{MATERIALS AND METHODS}

Field experiments were conducted at the Canterbury Agricultural Centre Campus, Lincoln, and the Pukekohe Research Station, Pukekohe, in February 2005, to test the response of both western flower thrips and onion thrips to the chemicals.

The water traps used were 2-litre white plastic containers $(178 \times 178 \times 80 \mathrm{~mm})$ (Viscount Plastics, New Zealand) set out in Latin Squares. Each trap contained approximately 1.7 litres of water and a few drops of formalin and Tween 20. A $2 \mathrm{ml}$ glass vial (Agilent, USA) (two glass vials for treatment 5) was suspended over the middle of each water trap with a piece of wire $(0.5 \mathrm{~mm}$ diameter $)$. Each vial contained a roll of Whatman No.1 filter paper $(40$ x $40 \mathrm{~mm}$, Whatman International, England $)$ that projected $1 \mathrm{~cm}$ above the top of the vial to create a wick. The five treatments were vials containing (1) water $(1 \mathrm{ml})$; (2) p-anisaldehyde only $(1 \mathrm{ml})$; (3) methyl isonicotinate only $(1 \mathrm{ml})$; (4) $p$-anisaldehyde $(0.5 \mathrm{ml})$ and methyl isonicotinate $(0.5 \mathrm{ml})$ mixed in the same vial or $(5) p$-anisaldehyde $(0.5 \mathrm{ml})$ and methyl isonicotinate $(0.5 \mathrm{ml})$ in separate vials.

At both locations the water traps were put in position in the field with lids on. The lids were then removed and the appropriate treatment vials added. At the end of the bioassay the vials were removed and lids replaced before they were taken from the field. In this way the trial set-up and take down were limited to approximately 5 minutes each. By replacing the lid on the traps at the end of the exposure period thrips on the inside rim of the trap above the water were included in the total thrips count for each sample. The traps were stored at $5^{\circ} \mathrm{C}$ until the thrips were extracted from the traps by sieving the water through a fine mesh.

At Lincoln, five replicates of the five treatments were laid out in a $5 \times 5$ grid $(10 \mathrm{~m}$ apart) in a mixed pasture field at the Canterbury Agricultural Centre Campus, Lincoln, on 9 February 2005 from 10.30 am to 2.30 pm (4 h). Grass and cereal fields surrounded the trial area, with a poplar (Poplar nigra L.) shelter row on the south-east side. The water traps were placed on top of similar inverted containers on the ground.

At Pukekohe, five replicates of the five treatments were laid out in a 5 x 5 grid $(7 \mathrm{~m}$ apart) on bare ground at Pukekohe Research Station, Pukekohe, on 15 February 2005 from 10.30 am to $4.30 \mathrm{pm}(6 \mathrm{~h})$. Surrounding vegetation comprised mainly of vegetable crops including lettuce and maize. The trial was adjacent to lettuces known to be infested with western flower thrips.

For both trials, all Terebrantia thrips from each water trap were counted (few Tubulifera thrips were found). For Lincoln, a subsample of thrips was mounted on microscope slides for identification using the following criteria: (a) for $<50$ per trap, all thrips were mounted, (b) for 51 to 100 per trap, 25 thrips were mounted, (c) for 101 to 200 per trap, 50 thrips were mounted and (d) for $>200$ per trap, 100 thrips were mounted. The total number of thrips within species per water trap was estimated using the proportions found in the sub-samples. For Pukekohe, all Terebrantia thrips caught in the water traps were 
sorted and mounted onto microscope slides for identification. Thrips were identified according to Mound \& Walker (1982) with allowance for several additions/corrections in thrips species since that time (L. Mound, pers. comm.).

The mean onion thrips catches were analysed using randomised block ANOVA. Data from the Lincoln site were first converted to an estimated onion thrips trap catch (as a result of subsampling) using the formula: estimated onion thrips catch $=$ no. onion thrips identified in sample $\times$ total no. thrips in sample / no. thrips identified from sample. Fisher's Least Significant Differences (LSD) at the 5\% level were used for comparisons between the treatment means.

\section{RESULTS}

Most thrips trapped at both Lincoln and Pukekohe (97\% and 92\%, respectively) were onion thrips. Very few ( $<1.6$ per trap) western flower thrips were caught in Pukekohe, and none were caught at Lincoln, therefore no analysis was carried out on these data. In total, nine thrips species were identified from Lincoln and 10 from Pukekohe traps. Thrips species, other than onion thrips, were found in relatively small numbers (Table 1) and differences between treatments were not analysed, although the presence/ absence of these species with respect to treatment has been noted.

Traps baited with $p$-anisaldehyde caught significantly more onion thrips than no odour traps at Lincoln $(7 \times)$ but not at Pukekohe $(2 \times)$. Methyl isonicotinate baited traps caught significantly more onion thrips $(30 \times$ at Lincoln, $5 \times$ at Pukekohe) than no odour traps. Also, significantly more thrips were caught in traps with methyl isonicotinate than in traps with $p$-anisaldehyde at both sites (Table 1). For the combined treatments of $p$-anisaldehyde and methyl isonicotinate (mixed in the same vial and in separate vials) total numbers of onion thrips were the same as or lower than the strongest single attractant, methyl isonicotinate, at both sites.

Other flower thrips were caught in low numbers, and most were found only in traps with odour chemicals (i.e. treatments 2-5). At Lincoln, Thrips obscuratus (male and female) were not caught in no odour traps but were present in all odour chemical treatments. Thrips australis (males) and T. physapus (females) were not caught in no odour traps but were present in at least one of the single odour chemical treatments. Ceratothrips frici (males) were caught in no odour traps and in traps with combined odour treatments (separate vials). At Pukekohe T. obscuratus (male and female), T. australis (male), T. vulgatisimus (female) and $F$. occidentalis (male and female) were not caught in no odour traps but were present in most odour chemical treatments. Thrips physapus (male and female) and $C$. frici (males) were not caught in no odour traps but were present in the combined odour chemical treatments. Ceratothrips frici (females) were not caught in no odour traps but present in traps with one of the single odour chemical treatments. Only T. australis (female), F. intonsa (male and female) and Microcephalothrips abdominalis (female) were found in both no odour and odour traps. There was no apparent effect of combining the two odour chemicals on trap capture at low numbers with respect to the presence or absence of flower thrips.

\section{DISCUSSION}

In accordance with other studies (Kirk 1985; Teulon et al. 1993; Murai et al. 2000) these results indicate that $p$-anisaldehyde is an effective chemical lure for onion thrips. Additionally, these results confirm a recent study (D.A.J. Teulon, unpubl. data) showing that methyl isonicotinate is a much more effective chemical lure for onion thrips than $p$-anisaldehyde. Indeed, the results of D.A.J. Teulon (unpubl. data) indicate that methyl isonicotinate and a closely related compound, ethyl isonicotinate, are the strongest chemical lures so far identified for this species. 
TABLE 1: Mean numbers of the different thrips species caught per water trap in the five treatments at Lincoln and Pukekohe.

\begin{tabular}{|c|c|c|c|c|c|}
\hline & \multirow{2}{*}{$\begin{array}{c}\text { No } \\
\text { odour }\end{array}$} & \multirow{2}{*}{$\begin{array}{l}p \text {-anis- } \\
\text { aldehyde }\end{array}$} & \multirow{2}{*}{$\begin{array}{c}\text { methyl } \\
\text { isonicotinate }\end{array}$} & \multicolumn{2}{|c|}{$\begin{array}{c}p \text {-anisaldehyde }+ \\
\text { methyl isonicotinate }\end{array}$} \\
\hline & & & & Mixed & Separate \\
\hline \multicolumn{6}{|l|}{ Lincoln } \\
\hline Aeolothrips fasciatus & 0.0 & 0.2 & 0.0 & 0.0 & 0.0 \\
\hline Chirothrips manicatus 우 & 0.0 & 0.0 & 0.5 & 0.0 & 0.0 \\
\hline Limothrips cerealium & 1.3 & 0.4 & 0.4 & 0.4 & 0.7 \\
\hline Anaphothrips obscurus 우 & 0.2 & 0.0 & 0.0 & 0.0 & 0.0 \\
\hline Ceratothrips frici $i^{1} \bigcirc^{7}$ & 0.2 & 0.0 & 0.0 & 0.0 & 0.8 \\
\hline Thrips australis ${ }^{1} \sigma^{7}$ & 0.0 & 0.6 & 0.0 & 0.0 & 0.0 \\
\hline Thrips obscuratus $^{1}$ Q & 0.0 & 0.2 & 1.0 & 2.0 & 2.1 \\
\hline Thrips obscuratus ${ }^{1} 0^{7}$ & 0.0 & 0.4 & 0.4 & 1.0 & 0.8 \\
\hline Thrips physapus ${ }^{1}$ ㅇ & 0.0 & 0.2 & 0.5 & 0.0 & 0.0 \\
\hline Thrips tabaci ${ }^{1}$ ㅇ & $7.1 \mathrm{a}^{2}$ & $49.2 b$ & $203.9 \mathrm{~d}$ & $137.4 \mathrm{c}$ & $199.3 d$ \\
\hline \multicolumn{6}{|l|}{ Pukekohe } \\
\hline Anaphothrips obscurus 우 & 0.0 & 0.0 & 0.0 & 0.2 & 0.2 \\
\hline Ceratothrips frici ${ }^{1} \uparrow$ & 0.0 & 0.0 & 0.0 & 0.2 & 0.0 \\
\hline Ceratothrips frici ${ }^{1} 0^{7}$ & 0.0 & 0.0 & 0.4 & 0.0 & 0.0 \\
\hline Frankliniella occidentalis $^{1}$ 우 & 0.0 & 0.0 & 0.6 & 1.2 & 0.2 \\
\hline Frankliniella occidentalis ${ }^{1} \mathrm{O}^{7}$ & 0.0 & 0.8 & 1.6 & 0.4 & 0.8 \\
\hline Frankliniella intons $a^{1}$ ㅇ & 0.8 & 0.2 & 0.6 & 0.0 & 0.0 \\
\hline Frankliniella intons $a^{1} 0^{7}$ & 0.2 & 0.0 & 0.6 & 0.6 & 0.4 \\
\hline Microcephalothrips abdominalis ${ }^{1}$ ㅇ & 0.2 & 0.0 & 0.0 & 0.0 & 0.0 \\
\hline Thrips australis ${ }^{1} q$ & 0.2 & 0.0 & 0.4 & 0.0 & 0.2 \\
\hline Thrips australis ${ }^{1} \mathrm{O}^{7}$ & 0.0 & 0.2 & 0.4 & 0.0 & 0.2 \\
\hline Thrips obscuratus ${ }^{1}$ q & 0.0 & 0.4 & 0.6 & 0.4 & 0.4 \\
\hline Thrips obscuratus ${ }^{1} 0^{7}$ & 0.0 & 0.2 & 0.2 & 0.4 & 0.0 \\
\hline Thrips physapus ${ }^{1}$ q & 0.0 & 0.0 & 0.0 & 0.2 & 0.4 \\
\hline Thrips physapus ${ }^{1} 0^{7}$ & 0.0 & 0.0 & 0.0 & 0.0 & 0.2 \\
\hline Thrips tabaci ${ }^{1}$ ㅇ & $18.0 \mathrm{a}$ & $33.2 \mathrm{ab}$ & $88.6 c$ & $57.0 \mathrm{bc}$ & $78.0 \mathrm{c}$ \\
\hline Thrips vulgatisimus ${ }^{1}$ q & 0.0 & 1.2 & 3.6 & 1.0 & 1.0 \\
\hline
\end{tabular}

${ }^{1}$ Flower-inhabiting species according to records in Mound \& Walker (1982) and Moritz et al. (2004).

${ }^{2}$ Means with the same letter are not significantly different at $P<0.05$.

The present results also indicate that the odour chemicals tested may be useful for trapping flower thrips when there is a low number of these species. For flower-inhabiting species other than onion thrips, three out of four species were only found in odour chemical treatments at Lincoln and five out of eight at Pukekohe.

Numbers of western flower thrips caught in all traps at Pukekohe were relatively low, despite the close proximity of the trial to lettuces infested with western flower thrips. Methyl isonicotinate is an effective lure for western flower thrips in greenhouse studies 
in New Zealand (Davidson et al. 2007) and the Netherlands (D.A.J. Teulon, unpubl. data; R.W.H.M. van Tol, unpubl. data), as well as in similar outdoor field studies in California (D.A.J. Teulon, unpubl. data). There is no clear explanation why so few western flower thrips were caught in the present trials, although no western flower thrips were caught in a $7.5 \mathrm{~m}$ high suction trap approximately $400 \mathrm{~m}$ from the trial during the trapping period (D.A.J. Teulon, unpubl. data).

Despite the odour chemicals being structurally different, there was no evidence that their combined use improved thrips capture, either at relatively high or low thrips numbers. It is unlikely that differences in the volume of odour in the separate and combined treatments affected this as there was enough liquid in the vials for the duration of the trapping period. There are no published studies on combined odours for attracting thrips. Although, Teulon et al. (2005) used combinations of odours they did not compare them with single compounds. Other insect species studies have indicated that combinations can increase trap capture (Robackers et al. 1992; Rappaport et al. 2000; Landolt et al. 2001; Aldrich et al. 2004) or decrease trap capture (Robacker \& Heath 1997; Zhang \& Schlyter 2004), but there is little discussion as to why these differences might occur.

Chemical analyses of mixed chemicals showed no chemical reactions in the laboratory (C.E. Sansom, unpubl. obs.). Given that the mixtures of odour chemicals in this study bought about similar or lower thrips capture, it could be that there is only one thrips odour receptor for the odour chemicals used in the present trials. The lower thrips capture in the mixed odour chemical traps in the field trials (significantly lower for Lincoln but not for Pukekohe) could be explained by a laboratory observation that a 1:1 mixture of the two compounds at the top of a filter paper wick was initially the same as the liquid mixture, but after 3 hours the relative amount of anisaldehyde was higher (C.E. Sansom, unpubl. obs.).

Under the experimental conditions described in these experiments there was no evidence that mixing different odour chemical lures together increased thrips trap catch. However, as little is understood of the mechanisms behind the response of thrips to odours (Teulon et al. 1999; Berry et al. 2006), this does not mean that odour mixtures may not improve thrips trap catch for other odour chemical combinations and/or other thrips species.

\section{ACKNOWLEDGEMENTS}

We thank Ruth Butler for assistance in the trial design, Catherine Sansom for chemical analyses of the mixture composition and the Crop \& Food Research Entomology team for assisting in the field trials. This research was funded by New Zealand's Foundation for Research, Science and Technology through the Better Border Biosecurity (B3) Programme.

\section{REFERENCES}

Aldrich JR, Zhang QH, Zhang AJ 2004. Synergistic chemical attraction of the eastern yellowjacket, Vespula maculifrons (Hymenoptera: Cespidae). Journal of Entomological Science 39(4): 643-653.

Berry N, Butler RC, Teulon DAJ 2006. Responses of New Zealand flower thrips (Thrips obscuratus) to synthetic and natural stimuli (odour and colour) in a wind tunnel. New Zealand Journal of Crop and Horticultural Science 34: 121-129.

Davidson MM, Butler RC, Winkler S, Teulon DAJ 2007. Pyridine compounds increase trap capture of Frankliniella occientalis (Pergande) in a covered crop. New Zealand Plant Protection 60: 56-60.

Davidson MM, Teulon DAJ, Perry NB 2005. Insect behavior modifying compounds. International Publication Number: WO 2005/046330, AL. Australian Patent office, Woden, Australia. 
Imai T, Maekawa M, Murai T, Imai T, Maekawa M 2001. Attractiveness of methyl anthranilate and its related compounds to the flower thrips, Thrips hawaiiensis (Morgan), T-coloratus Schmutz, T-flavus Schrank and Megalurothrips distalis (Karny) (Thysanoptera : Thripidae). Applied Entomology and Zoology 36(4): 475-478.

Kirk WDJ 1985. Effect of some floral scents on host finding by thrips (Insecta, Thysanoptera). Journal of Chemical Ecology 11(1): 35-43.

Landolt PJ, Adams T, Reed HC, Zack RS 2001. Trapping alfalfa looper moths (Lepidoptera : Noctuidae) with single and double component floral chemical lures. Environmental Entomology 30(4): 667-672.

Lewis T 1997. Thrips as Crop Pests. CAB International. Wallingford, UK.

Moritz G, Mound LA, Morris DC, Goldarazena A 2004. Pest Thrips of the World. Lucid CD-ROM. The University of Queensland, Australia.

Mound LA 1996. The thysanoptera vector species of tospoviruses. Acta Horticulturae 431: 298-309.

Mound LA, Walker AK 1982. Terebrantia (Insecta: Thysanoptera). Fauna of New Zealand 1. Science Information Publishing Centre, Wellington, NZ. Pp. 1-113.

Murai T, Imai T, Maekawa M 2000. Methyl anthranilate as an attractant for two thrips species and the thrips parasitoid Ceranisus menes. Journal of Chemical Ecology 26 (11): 2557-2565.

Nielsen MC, Fletcher CD, Teulon DAJ 2004. Monitoring thrips flight with 7.5 metre high suction traps. New Zealand Plant Protection 57: 339.

Rappaport NG, Stein JD, Mora AAD, DeBarr G, de Groot P, Mori S 2000. Responses of Conophthorus spp. (Coleoptera: Scolytidae) to behavioral chemicals in field trials: A transcontinental perspective. Canadian Entomologist 132(6): 925-937.

Robacker DC, Heath RR 1997. Decreased Attraction of Anastrepha ludens to Combinations of Two Types of Synthetic Lures in a Citrus Orchard. Journal of Chemical Ecology 23(5): 1253-1262.

Robacker DC, Warfield WC, Flath RA 1992. A 4-component attractant for the Mexican fruit-fly, Anastrepha ludens (Diptera, Tephritidae), from host fruit. Journal of Chemical Ecology 18(7): 1239-1254.

Terry LI 1997. Host Selection, Communication and Reproductive Behavior. In: Lewis T ed. Thrips as Crop Pests. University Press, Cambridge, UK. Pp. 65-118.

Teulon DAJ, Nielsen M-C 2005. Distribution of western (glasshouse strain) and Intonsa flower thrips in New Zealand. New Zealand Plant Protection 58: 208-212.

Teulon DAJ, Nielsen M-C, Muir CA, Burnip GM, McCarthy BJT 2005. Assessing a possible flower thrips incursion using flower samples and semiochemicals. New Zealand Plant Protection 58: 324 (Abstract only).

Teulon DAJ, Penman DR 1996. Thrips (Thysanoptera) seasonal flight activity and infestation of ripe stonefruit in Canterbury, New Zealand. Journal of Economic Entomology 89(3): 722-734.

Teulon DAJ, Hollister B, Cameron EA 1993. Behavioural responses of western flower thrips to anisaldehyde, and implications for trapping in greenhouses. Bulletin OILB/SROP 16(2): 177-180.

Teulon DAJ, Hollister B, Butler RC, Cameron EA 1999. Colour and odour responses of flying western flower thrips: wind tunnel and greenhouse experiments. Entomologia Experimentalis et Applicata 93: 9-19. 